DOI https://doi.org/10.36059/978-966-397-244-2-2-6

Ковейно Ю. В.

старший викладач кафедри права та публічного адміністрування Маріупольський державний університет

м. Маріуполь, Донецька область, Україна

\title{
ОРГАНІЗАЦІЙНО-ПРАВОВА ОСНОВА УПРАВЛІННЯ ПОВОДЖЕННЯ З ВІДХОДАМИ В УКРАЇНІ
}

В сучасних умовах розвитку державності достатня увага приділяється питанням сталого розвитку, що є визначальним на шляху інтеграції України до європейського співтовариства. Проблема управління відходами є однією з найактуальніших, не тільки на національному рівні, а також міжнародному, що потребує значної уваги. Проведене дослідження дало змогу проаналізувати інституційно-організаційні засади поводження з відходами. Проаналізовано основні законодавчі акти, у тому числі міжнародні щодо поводження з відходами. Зосереджено увагу на системі органів які здійснюють управління в сфері поводження з відходами, серед яких виділено органи загальної та спеціальної компетенції. Вказано на недоліки органів спеціальної компетенції в сфері поводження з відходами, зокрема Державної екологічної інспекції, також зазначено причини неефективної діяльності вказаних органів. Запропоновано та обгрунтовано шляхи вирішення проблемних питань в сфері поводження з відходами, зокрема щодо вдосконалення законодавства та організації діяльності суб'єктів поводження з відходами, включаючи органи державної, регіональної влади, місцевого самоврядування, а також суб'єктів підприємницької діяльності, діяльність яких здійснює негативний вплив на навколишнє середовище тощо.

\section{Вступ}

Одним з основоположних прав, наданих Конституцією Україні $1996 \mathrm{p}, \epsilon$ право на сприятливе навколишнє середовище, достовірну інформацію про її стан і на відшкодування шкоди, заподіяної здоров'ю або майну людини екологічним правопорушенням (ст. 50). В повній мірі реалізація наданого права повинна здійснюватися і при розвитку інфраструктури 
Новітні досягнення та вектори розвитку сучасної юриспруденції

об'єктів поводження з відходами, що спостерігається останніми роками на всій території України.

Проблема відходів $\epsilon$ на сьогоднішній день однією 3 найважливіших проблем не тільки в Україні, а й в у всьому світі. Кількість тих відходів, яку утворює держава, говорить в першу чергу про економічну ситуацію в країні, а також про соціальний і технологічний розвиток суспільства в цілому. Багато в чому та несприятлива екологічна ситуація, яка спостерігається в нашій державі, виникла в сфері зберігання, утилізації та розміщення відходів виробництва та споживання. Значних економічних збитків державі завдає відсутність ефективності поводження 3 відходами, відмова від вторинної переробки, нераціональне використання природних ресурсів, що становить загрозу здоров'ю громадян. Спостерігається висока ступінь завантаженості територій відходами. Розширюються земельні ділянки для розміщення відходів виробництва і споживання, що тягне за собою негативні наслідки впливу на навколишнє середовище.

Забезпечення екологічно безпечного поводження з відходами $\epsilon$ однією з найбільш серйозних і актуальних проблем сучасності, яка знаходиться у фокусі інтересів держави, особливо в зв'язку зі збільшенням кількості відходів, які не залучаються у вторинний господарський оборот, а розміщуються на полігонах і звалищах, що призводить до забруднення грунтів, виводу продуктивних сільськогосподарських угідь 3 обороту, накопичення забруднюючих речовин в надрах водних об'єктів.

Розміщення невідсортованих відходів на звалищах і полігонах $\epsilon$ найпопулярнішим способом розміщення відходів саме в Україні. Через нераціональне використання пропадає 90\% корисної продукції, яка має реальний попит на ринку вторинної сировини, крім цього, зміст цінних компонентів видобутої сировини нерідко аналогічно їх вмісту в відходах. Проблема утилізації та переробки практично не вирішується.

Сформована за десятиліття система поводження з відходами на території нашої країни потребує докорінної перебудови від повсюдного поховання на користь ефективно застосовуваних в світовій економіці технологій ресурсозбереження, обробки, утилізації та знешкодження таких відходів. При цьому в якості однієї 3 основних причин відставання України в реалізації процесів обробки і подальшої утилізації відходів вказується відсутність організованої ефективної системи роздільного збору 
відходів (як в житловому секторі, так і на підприємствах), а також подальшої обробки, утилізації та знешкодження таких відходів в промисловому масштабі, залучення утильних фракцій в господарський оборот. Рішення проблеми забезпечення екологічно безпечної утилізації та знешкодження відходів можливо тільки шляхом застосування комплексного підходу, що включає в себе систему заходів різного характеру - екологічних, технологічних, економічних і правових, одне з центральних місць якої займають саме правові заходи. Разом з тим слід зазначити, що в Україні на сьогоднішній день відсутнє комплексне правове регулювання відносин у галузі охорони навколишнього середовища при поводженні 3 відходами виробництва i споживання, що обумовлено перш за все відсутністю закріпленої в праві системи екологічних вимог спеціального характеру до різних видів діяльності щодо поводження з відходами, а також до об'єктів, на яких зазначена діяльність здійснюється.

Таким чином, проблеми правового забезпечення охорони навколишнього середовища в галузі поводження 3 відходами виробництва i споживання, обумовлюють необхідність теоретичної розробки та практичного впровадження екологічно значимих правових механізмів, спрямованих на регулювання відносин з охорони навколишнього середовища при здійсненні діяльності щодо поводження 3 відходами, що обумовлює надзвичайну актуальність теми цього дослідження.

\section{1. Правове забезпечення в сфері поводження з відходами виробництва і споживання в Україні}

Відходи виробництва та споживання є однією з найбільш істотних глобальних екологічних проблем сучасності, рішення якої 3 плином часу стає все більш необхідною. Значимість вирішення проблеми відходів в світовому співтоваристві сприйнята на міждержавному рівні, що зумовлює особливу важливість пошуку додаткових шляхів міжнародного співробітництва в сфері поводження з відходами, а також вектори розвитку національного права у зазначеній сфері.

Питання про міжнародно-правове регулювання поводження 3 відходами важливо досліджувати в контексті статті 9 Конституції України [1]. Згідно цієї статті міжнародні договори України, згода на обов'язковість яких надана Верховною Радою України, $\epsilon$ складовою частиною її правової системи. Відповідно, $\epsilon$ 
науковий і практичний інтерес розглянути міжнародно-правові документи, що містять загальновизнані принципи і норми міжнародного права в сфері поводження 3 відходами виробництва і споживання.

На сучасному етапі розвитку світової спільноти в умовах глобалізації та економічної інтеграції відбувається зміцнення міжнародного та регіонального співробітництва в галузі охорони навколишнього середовища. Це значно посилює інтеграційні процеси. I, як наслідок, ускладняється регулювання міжнародних економічних відносин, оскільки виникає конфлікт між розвитком регіональних економік і вимогами скоротити шкідливі викиди і забруднення.

у сферу національного та міжнародного екологічного регулювання потрапляють все нові відносини, які раніше не регулювалися на міжнародно-правовому рівні, виникають нові галузі або інститути, яких раніше взагалі не існувало. Так, в Україні поняття «відходи», що визнане i використовується в міжнародному праві, було законодавчо закріплено 1 липня 1999 року, коли вступила в силу ратифікована Україною Базельська конвенція від 22 березня 1989 року про контроль за транскордонним перевезенням небезпечних відходів та їх видаленням [2]. Зокрема, Базельська конвенція встановлює, що «відходи» представляють собою речовини або предмети, які видаляються, призначені для видалення або підлягають видаленню відповідно до положень національного законодавства. Ратифікована Україною конвенція про контроль за транскордонне перевезення небезпечних відходів та їх видалення, зобов'язує вживати належних заходів щодо забезпечення мінімуму утворення відходів на території країни з урахуванням соціальних, технічних і економічних аспектів, що вимагає не тільки вирішення проблеми утилізації накопичуваних відходів виробництва i споживання, але і технологічної модернізації діючих виробництв.

Також, слід відзначити Стокгольмську конвенцію про стійкі органічні забруднювачі (СО3) 2001 року [3], яка $€$ новим вектором впливу на регіональні економіки країн що підписали дану конвенцію, вибудовуючи перед ними складні виклики.

Охорона навколишнього природного середовища та раціональне використання природних ресурсів завжди розглядалися світовою спільнотою як найбільш актуальні i важливі проблеми сучасності, які в значній мірі визначають умови 
існування і розвитку людської цивілізації. 3 урахуванням того, що Україна орієнтована на інтеграцію в спільний з Європейським Союзом економічний простір, яка неможлива без дотримання принципів Базельської конвенції (Конвенція про контроль за транскордонним перевезенням небезпечних відходів та їх видаленням) і розробки досить близьких за змістом механізмів в сфері управління відходами, вельми актуальною і практично значущою проблемою залишається розробка ефективної системи управління відходами з метою забезпечення екологічної безпеки, спрямованої як на поліпшення нормативно-законодавчої бази в сфері поводження з відходами, так і на розробку комплексу технологічних рішень по збору, використанню, знешкодженню, транспортуванню, розміщенню відходів, організації екологічного моніторингу, оцінки і управління ризиками, способів взаємодії різних відомств і організацій.

Вперше Європейський союз (далі - ЄС) заговорив про проблему відходів в 1975 році, коли була прийнята Директива Ради ЄC 75/442/ЄЕС, що передбачає заборону на несанкціоноване складування, поховання і утилізацію відходів. Документом передбачалося створення міжнародної мережі установок для видалення відходів з використанням безпечних технологій, що не потребують значних витрат (ст. 5 Директиви Ради ЄС 75/442/ЄЕС). Створеним підприємствам 3 переробки було дозволено перебувати в будь-якій формі власності, але з отриманням дозволу на поводження з відходами у відповідних національних або міжнародних організацій. На сьогоднішній день, ЄС прийнято більше 20 законодавчих актів в сфері поводження з відходами. Серед них Директива Ради ЄС 96/61/ЄС від 24 вересня 1996 року про комплексне запобігання та контроль забруднень, Директива 2000/76/€С зі спалювання відходів від 4 грудня 2000 року Директива про наземні звалища 99/31/ЄС від 16 липня 1999 року та ін. Цими документами передбачено скорочення числа відходів, що підлягають знищенню, i поступовий перехід до їх використання в якості вторинних ресурсів. Інструментами для цього послужила система оподаткування джерел відходів, розробка стратегії переробки, вдосконалення існуючих схем кількісних і якісних показників відходів.

Законодавство в сфері поводження з відходами тісно пов'язане 3 іншими напрямками природоохоронного законодавства (наприклад, Директивою комплексного контролю та запобігання 
забрудненню 96/61/ЄС або Директивою Севезо II 96/82/€C) i нормативно-правовими актами необов'язкового (рекомендаційного) характеру. Тому структура законодавчих актів $€ C$, які стосуються поводження 3 відходами, досить складна, і для спрощення процедури ідентифікації цих законодавчих актів можна використовувати підходи, пропоновані ISO 14001 Система екологічного менеджменту.

Вимоги та організаційні заходи управління відходами в Україні визначені законодавством у сфері охорони навколишнього середовища, іншими нормативними документами, а також ратифіковані в установленому порядку міжнародні договори, учасницею яких $є$ Україна.

У республіці діє значна кількість нормативних правових актів, які регулюють систему управління відходами та мають ряд вимог до процесів поводження з відходами.

Концепція та основні положення законодавства 3 охорони навколишнього середовища базуються на нормах Конституції України. Відповідно до ст. 50 Конституції, кожен громадянин має право на сприятливе для життя і здоров'я екологічне середовище і на відшкодування завданої шкоди порушенням цього права.

Земельний, Лісовий, Водний кодекси України, кожен в силу своєї дії і в рамках свого охоплення містить певні норми, що регулюють відносини в сфері поводження з відходами. Стаття 167 Земельного кодексу України встановлює вимоги щодо охорони земель від забруднення небезпечними речовинами. Стаття 105 Лісового кодексу України передбачає відповідальність за засмічення лісів побутовими і промисловими відходами, яке тягне за собою дисциплінарну, адміністративну, цивільно-правову або кримінальну відповідальність відповідно до закону. Стаття 75 Водного кодексу України встановлює порядок захоронення забруднюючих речовин, відходів виробництва, стічних вод у глибокі підземні водоносні горизонти та повернення супутньопластових вод нафтогазових родовищ до підземних горизонтів.

Кримінальним кодексом України і Кодексом України про адміністративні правопорушення визначена міра відповідальності за порушення вимог законодавства у сфері поводження відходів.

Базовий Закон України «Про охорону навколишнього середовища» [4] визначає основоположні принципи і заходи охорони навколишнього середовища, а також загальні вимоги до безпечного поводження з відходами виробництва та споживання. 
Зокрема, цей Закон встановлює систему обліку і нормування, що включає вимоги і заходи по: веденню державного обліку відходів, що утворюються і розміщуються в навколишньому середовищі (ст. 24); лімітуванню і встановленню гранично допустимих норм скидів забруднюючих речовин (ст. 44).

Правові засади регулювання поводження 3 відходами, передбачені цим Законом, включають ряд вимог до господарської та іншої діяльності щодо: проведення оцінки впливу на навколишнє середовище (ОВНС) об'єктів, пов'язаних 3 поводженням з відходами (ст. 51); прийняття ефективних заходів по знешкодженню, переробці, утилізації, складування або захоронення виробничих і побутових відходів (ст. 51); здійснення державного контролю за дотриманням вимог щодо поводження 3 відходами (ст. 55); організації та проведення моніторингу за станом навколишнього середовища на об'єктах, пов'язаних 3 поводженням з відходами (ст. 22); інформування зацікавлених сторін (Розділ V).

Крім того, Закон України «Про охорону навколишнього середовища» встановлює компетенцію державних органів, повноваження громадських об'єднань, права та обов'язки громадян, природокористувачів в галузі поводження з відходами, відповідальність за екологічні правопорушення і порядок вирішення спорів у сфері поводження з відходами.

Закон України «Про відходи» [5] є основним Законом України, що визначає державну політику в сфері поводження з відходами виробництва та споживання і регулює відносини, що виникають в процесі життєвого циклу відходів, а також державного управління, нагляду та контролю у сфері поводження з відходами. Цей Закон визначає основні засади державної політики у галузі поводження з відходами та повноваження державних органів i органів місцевого самоврядування, регламентує вимоги щодо поводження з відходами, транскордонного перевезення відходів, ліцензування діяльності поводження з відходами, державного, виробничого і громадського контролю, нормування поводження 3 відходами, державному обліку і ведення кадастру відходів, економічного регулювання, заходів відповідальності та вирішення спорів в галузі поводження з відходами.

Законом встановлено загальні вимоги щодо поводження 3 відходами під час експлуатації діючих об'єктів в частині здійснення інвентаризації відходів та державної статистичної 
Новітні досягнення та вектори розвитку сучасної юриспруденції

звітності, моніторингу та відновлення місць розміщення відходів. Також, цим нормативним актом передбачено вимоги щодо вибору місць будівництва об'єктів для розміщення відходів, внесення їх до державного кадастру відходів, очистки населених пунктів від відходів, організацію раціональної системи збору відходів, яка передбачає роздільний збір цінних компонентів, їх тимчасове зберігання, регулярне вивезення та знешкодження.

Однак, слід відзначити, що на сьогоднішній день, Закон України «Про відходи» застарів і багато його положень не актуальні, або суперечать тим законодавчим актам, які були розроблені і прийняті пізніше. Так, наприклад, з огляду на те, що Закон «Про відходи» $є$ базовим в сфері поводження з відходами, в ньому не визначені багато видів відходів, які на сьогоднішній день знаходяться в поводженні на території України, дається лише визначення «відходів виробництва», «побутові відходи», «рідкі відходи» і «тверді відходи». Використовуваний в цьому ж документі термін ««відходів споживання» і «небезпечних відходів»» немає визначення. Також законом не охоплені такі види відходів як медичні, біологічні, будівельні, електронні та інші відходи; даний законодавчий акт не забезпечений необхідними відсилочними нормами на інші нормативні правові акти, які тією чи іншій мірою забезпечують регулювання різних видів відходів. Відповідно до ст. 34 Закону «По відходи» стверджується, що всі небезпечні відходи за ступенем їх шкідливого впливу на людину i навколишнє середовище поділяються на класи, хоча не дає розуміння принципу поділу на класи небезпеки, не дає визначення класу небезпеки, до того ж не забезпечений відсилочними нормами на нормативно-правові акти, які регламентують дані положення.

Отже, прийняття Закону України «Про відходи» стало значним кроком у регулюванні відносин у досліджуваній сфері. Але цей Закон не зміг повною мірою забезпечити ефективне регулювання поводження з відходами. Він встановив вимоги загального характеру стосовно до багатьох важливих аспектів поводження з відходами та носить рамковий характер. У ньому практично відсутні норми процесуального характеру. Хоча Закон передбачає залучення відходів в господарський оборот в якості додаткових джерел сировини, він не передбачає конкретного механізму такого залучення. Для цього, як мінімум, потрібно 
законодавчо встановити розмежування відходів на ті, які не можуть бути використані і відходи, що представляють собою вторинні матеріальні ресурси. Особливо явно рамковий характер зазначеного закону проявляється стосовно економіко-правового механізму поводження з відходами виробництва та споживання. Встановлюючи принцип використання методів економічного регулювання діяльності в галузі поводження з відходами з метою зменшення кількості відходів та залучення їх до господарського обороту, Закон не передбачив механізму його реалізації. Удосконалення економіко-правового механізму поводження 3 відходами виробництва та споживання, перш за все, передбачає законодавче закріплення в Законі України «Про відходи» i Податковому кодексі України конкретних заходів економічного стимулювання у вигляді податкових, кредитних, цінових пільг, податкових дискримінацій і т. д.

Положення Закону України «Про відходи» не охоплює i відповідно не регулює всю систему поводження з відходами. У зв'язку 3 вищевикладеним, Закон України «Про відходи» потребує внесення змін та доповнень.

Тобто перед сучасною Україною виникає необхідність виробити новий погляд на проблему відходів. Так, у 2018 році Кабінетом Міністрів України було схвалено Національну стратегію поводження з відходами в Україні до 2030 року [6], таким чином підтримуючи європейські стандарти і принципи поводження з відходами. Поштовхом до прийняття Стратегії на державному рівні було підписання Угоди про асоціацію між Україною та $Є С$, завдяки прагненням нашої держави інтегрувати світові стандарти в національне законодавство. Нова Стратегія розроблена з метою впровадження принципів і методів економіки замкнутого типу, і переорієнтації на сучасні і екологічні методи боротьби з відходами. Новелою стало запровадження Регіональних планів управління відходами, що розроблюються для сприяння реалізації цієї Стратегії. Вказані плани, повинні базуватися насамперед на Національному плані управління відходами, який затверджено урядом на підставі розпорядження № 117-p від 20.02.2019 p [7]. Національний план управління відходами регламентує розроблення та затвердження в установленому порядку проектів регіональних планів управління відходами терміном виконання до 2020 року. Виконавцями Національного плану зазначено обласні та Київська міська 
держадміністрації, органи місцевого самоврядування (за згодою), Міндовкілля, Мінрегіон. Уперше Регіональний план управління відходами було прийнято у Вінницькій області на період до 2030 року. Метою РПУВ $є$ забезпечення сталого управління відходами в Вінницькій області 3 урахуванням положень концепції сталого розвитку та дотриманням ієрархії пріоритетів управління відходами.

Таким чином, сукупність таких нормативних правових актів, що регулюють поводження 3 відходами виробництва та споживання, в екологічному законодавстві оцінюється як підгалузь законодавства, що знаходиться в стані розвитку. Дане судження засноване на тому, що системі цих актів характерні такі ознаки: наявність свого предмета правового регулювання; єдність нормативних правових актів, що утворюють це законодавство; важливість соціально-економічного і політичного значення сфери правового регулювання; досить великий обсяг.

\section{2. Інституційно-організаційні засади системи управління поводження з відходами виробництва і споживання в Україні}

В сучасних умовах темпи зростання обсягів відходів визначаються не стільки темпами приросту населення, скільки зміною його доходів і способу життя, тобто проблема різкого зростання обсягів відходів виробництва і споживання в цілому $\epsilon$ наслідком зміни ціннісних орієнтирів суспільства. Склад відходів багато в чому змінився через прогрес в промисловості, підвищення рівня життя громадян, розширення ринку послуг. Безпека екологічних процесів і максимальне використання відходів $є$ одним із пріоритетних завдань при переробці відходів виробництва та споживання. На жаль, нині на більшій частині території України не дотримуються вимоги законодавства в сфері поводження з відходами виробництва і споживання. Крім того, юридичні особи, громадяни та органи державної влади i місцевого самоврядування, які наділені повноваженнями у сфері поводження 3 відходами, порушують законодавство у сфері поводження з відходами виробництва і споживання. Заходи, які виконуються регіонами щодо поліпшення екологічної ситуації, не дають позитивного результату, однією з основних причин чого $є$ відсутність уніфікованої методики збору, перевезення та знищення відходів. 
Новітні досягнення та вектори розвитку сучасної юриспруденції

Відсутність позитивного результату можна пояснити наступними причинами: виробники практично не несуть відповідальність за забезпечення екологічної безпеки продукції; немає економічного заохочення в сфері поводження з відходами; немає правових норм, що регулюють управління потоками відходів на регіональному рівні, включаючи зменшення обсягів відходів, які направляються на поховання.

Слід сказати, що тривалий період в правовому полі України питання поводження з відходами виробництва та споживання регулювалися фрагментарно, а чинне в цій сфері законодавство досить суперечливе, створює передумови екологічних правопорушень. Крім того, на сьогоднішній день немає дієвих методів забезпечення державного управління у сфері поводження 3 відходами. Зростаюча кількість і ускладнення морфологічного складу твердих побутових відходів (далі - ТПВ) привело людство до усвідомлення необхідності управління потоками відходів. Термін "Waste Management" (укр. - «управління відходами») [8], широко використовуваний в зарубіжній практиці, означає організацію поводження з відходами з метою зниження їх впливу на здоров'я людини і стан довкілля. Дане визначення містить чітке формулювання мети управління відходами. У вітчизняній науковій літературі та нормативній документації визначення терміну «управління відходами» відсутнє, а на практиці використовується термін «поводження з відходами», визначення якого дано в Законі України «Про відходи»: «дії, спрямовані на запобігання утворенню відходів, їх збирання, перевезення, сортування, зберігання, оброблення, перероблення, утилізацію, видалення, знешкодження і захоронення, включаючи контроль за цими операціями та нагляд за місцями видалення». Це визначення вказує на те, що поводження з відходами включає крім безпосередніх технологічних робіт з відходами (збирання, розміщення та ін.) організаційно-технологічне регулювання цих робіт, в тому числі попередження, мінімізацію, облік і контроль їх утворення. Мета регулювання в наведеному визначенні поняття «поводження з відходами» не сформульована.

У зв’язку з відсутністю будь-якої теоретичної і законодавчої бази в сфері управління відходами в Україні термін «управління відходами» найчастіше просто замінює термін «поводження 3 відходами» і позначає процеси розпорядження відходами, включаючи збір, транспортування, переробку або захоронення 
(сьогодні будь-який водій сміттєвоза або двірник може сказати, що він бере участь в системі управління відходами). Однак результати, досягнуті в цій галузі в європейських країнах, для України продовжують залишатися недосяжними.

Необхідність створення системи управління відходами усвідомлюється сьогодні вченими, політиками і практиками усіх країн світу. В прийнятій 15 липня 1975 р. Директиві № 75/442/ЄЕС (так званої «Рамкової директиви») [9], що $\epsilon$ першим законодавчим документом в галузі управління відходами, вперше сформульовані і законодавчо закріплені принципи поводження з відходами у вигляді ієрархії управління відходами.

Ієрархія управління відходами (універсальна модель поводження 3 будь-яким видом відходів) являє собою класифікацію дій з відходами за ступенем їх пріоритетності 3 точки зору мінімізації негативного впливу на навколишнє середовище i здоров'я людини і побудована на наступних принципах: запобігання або зниження утворення відходів; поділ відходів у джерела їх утворення; вторинне використання відходів шляхом повернення в виробничий процес; рециклінг (обробка відходів з метою отримання з них нових видів сировини або продукції); знешкодження відходів з метою зниження їх небезпеки для природного середовища; захоронення відходів (найменш краща альтернатива управління відходами).

При створенні міжнародних і національних планів і стратегій поводження $з$ відходами законодавство $Є C$ наказує керуватися цією ієрархією відходів. Європейський досвід управління поводженням 3 побутовими відходами - складний процес 3 багатьма залученими сторонами, який включає правові, технічні, економічні та екологічні аспекти. Ефективне управління поводження з відходами, що забезпечує досягнення поставлених цілей, має здійснюватися відповідно до теорії управління, згідно якої управління - це система різних форм і методів впливу суб'єкта управління на об’єкт управління для досягнення поставлених цілей. Пріоритетною метою управління відходами $\epsilon$ мінімізація негативного впливу відходів на навколишнє середовище і здоров'я людини. Системою управління відходами можна назвати такий процес взаємодії об'єкта управління і керуючої системи, який призводить до досягнення поставленої мети управління. Однак система управління побутовими відходами включає також важливі правові питання. Основним 
інструментом впливу на управління відходами в Україні $\epsilon$ законодавче та нормативне регулювання, але в ньому існують певні прогалини, які, як наслідок, призводять до неефективного функціонування всієї галузі в цілому: діюча система нормування скидів, викидів і утворення відходів суб'єктивна і дозволяє підприємствам встановлювати будь-який рівень впливу на навколишнє середовище; штрафи за негативний вплив на навколишнє середовище мінімальні і не створюють економічної мотивації для суб'єктів підприємництва 3 модернізації виробництва; відсутні економічні стимули для господарюючих суб'єктів щодо переходу на екологічно ефективні технології; при прийнятті рішень в сфері охорони довкілля доводиться долати велику кількість адміністративних бар'єрів. Також не створюється середовище для застосування нових управлінських механізмів, таких як екологічний аудит, страхування екологічних ризиків.

В системі управління відходами об'єктом управління є всі процеси поводження з відходами, які були перераховані вище. Суб'єктом управління (тобто керуючою системою) $є$ уповноважені державні, регіональні органи та органи місцевого самоврядування, що забезпечують процес управління у вказаній сфері. У Законі України «Про відходи» визначені повноваження суб'єктів управління відходами в Україні на кожному рівні управління. Зокрема, повноваження органів державної влади включають, перш за все, розробку і прийняття законів та інших нормативних актів та здійснення державного нагляду в галузі поводження з відходами. На регіональному рівні до повноважень належить розробка і реалізація регіональних програм, планів у сфері поводження з відходами і державний нагляд на об'єктах регіонального екологічного нагляду. Основні ж повноваження в сфері організації поводження з відходами передані органам місцевого самоврядування: організація збору, вивезення, утилізації та переробки побутових і промислових відходів.

Відзначимо, особливу роль органів публічного управління у системі управління поводження з відходами виробництва та споживання в Україні, як невід'ємної її складової. Проявом вищевказаного $\epsilon$ реалізація функцій та завдань у сфері поводження з відходами, які на них покладено відповідно до чинного законодавства. Враховуючи законодавчу базу та позиції чималої кількості науковців, відмітимо, що усі органи 
державного управління поводження з відходами виробництва i споживання в Україні поділяються на органи загальної та спеціальної компетенції. Провідне місце серед органів публічного управління що здійснюють управління у сфері поводження 3 відходами займають органи загальної компетенції. До таких органів, відповідно до Закону України «Про відходи» віднесені Кабінет Міністрів України, місцеві державні адміністрації та органи місцевого самоврядування. Зазначені органи мають особливий вид в силу того, що вирішення питань поводження 3 відходами не $\epsilon$ їх спеціальною функцією, а рішення цих органів мають певні територіальні межі дії і поширюються на всіх громадян i різні підприємства, установи, організації, які перебувають у межах території юрисдикції органів загальної компетенції.

Серед зазначених органів найбільш наближеними до проблемних питань поводження 3 відходами слід відзначити діяльність місцевих органів публічної влади. Так, відповідно до Закону України «Про відходи» та «Про місцеві державні адміністрації» [10] місцеві державні адміністрації в межах своїх повноважень здійснюють виконавчу владу на території відповідної адміністративно-територіальної одиниці, а також реалізують повноваження, делеговані їй відповідною радою на виконання функціональних повноважень у сфері поводження 3 відходами. Важливу роль у сфері поводження з відходами відіграють органи місцевого самоврядування та їх виконавчі комітети. Виключною компетенцією сільських, селищних, міських рад у сфері поводження з відходами, що передбачена п. 54 ст. 26 Закону України «Про місцеве самоврядування в Україні» $є$ вирішення питань у сфері поводження з небезпечними відходами відповідно до законодавства [11].

До органів спеціальної компетенції належать державні органи, на які покладено спеціальні функції у сфері поводження 3 відходами: Міністерство захисту довкілля та природних ресурсів України; Міністерство розвитку громад та територій України; Міністерство охорони здоров'я України; Державна екологічна інспекція України; Державна служба 3 питань геодезії, картографії та кадастру.

Отже, на сьогоднішній день, в Україні існує чимало органів спеціальної компетенції, які мають різноманітний вплив на 
сферу поводження з відходами, і які, на наш погляд, можна поділити на групи.

Так, до першої групи органів спеціальної компетенції можна віднести Міндовкілля, основні завдання якого визначені Постановою Кабінету Міністрів України про Міністерство захисту довкілля та природних ресурсів України, затвердженого постановою Кабінету Міністрів України від 25 червня 2020 року № 614 «Деякі питання Міністерства захисту довкілля та природних ресурсів» [12]. Серед широкого кола основних завдань, що покладені на Міндовкілля слід виокремити поводження 3 відходами, зокрема радіоактивними, з небезпечними хімічними речовинами. До органів спеціальної компетенції належить і Міністерство розвитку громад та територій України. Основні завдання Міністерства розвитку громад та територій України визначені Постановою Кабінету Міністрів України від 30 квітня 2014 р. № 197 «Про затвердження Положення про Міністерство розвитку громад та територій України» [13]. Одним із основних завдань цього органу $є$ поводження $з$ побутовими відходами, забезпечення розроблення та виконання державних програм у сфері поводження з побутовими відходами, планів та заходів у сфері поводження з побутовими відходами.

Сфера поводження 3 побутовими відходами передбачає дотримання державних санітарних правил і норм. Наказом Міністерства охорони здоров'я України від 08.06.2015 р. № 325 затверджено Державні санітарно-протиепідемічні правила i норми щодо поводження з медичними відходами [14].

До другої групи, основним контролюючим органом в сфері поводження з відходами, можна віднести Державну екологічну інспекцію (далі - ДЕI), яка діє на підставі Положення [15]. Також алгоритм роботи ДЕІ регламентований Законом України «Про основні засади державного нагляду i контролю у сфері господарської діяльності» [16]. Вказаний закон встановлює правила перевірки господарської діяльності підприємств під час планових і позапланових перевірок. Інструментами контролю ДЕІ є: приписи, штрафні санкції та розрахунок збитків. Більше 30\% перевірок ДЕІ пов'язані з відходами. У 2020 році було оголошено мораторій на здійснення планових перевірок у зв'язку 3 пандемією Covid 19, а на початку 2021 року було частково поновлено. Мова йде про понад 7 тисяч суб'єктів господарювання 3 найвищим ступенем ризику. В основному 
Державна екологічна інспекція здійснює діяльність у режимі позапланових перевірок, які формуються за скаргою фізичних осіб через сайт, гарячу лінію, електронною поштою, через SaveEcoBot. Також ДЕI працює за дорученням прем'єр-міністра. У 2021 році вказані доручення стосуються трьох напрямків, серед яких: медичні відходи (перевірка суб'єктів, які мають ліцензію на утилізацію), нафтопродукти, а це більше 500 суб'єктів, i незаконні сміттєзвалища [17]. Діяльність ДЕІ в умовах сьогодення викликає дискусії, серед яких більшість є негативні щодо якості та ефективності діяльності. Проте, $\epsilon$ й певні позитивні кроки, які все ж таки потребують вдосконалення та подальших реформ. Не дивлячись на відсутність коштів щодо сплати судового збору Держаною екологічною інспекцією, що $\epsilon$ однією з причин не звернення до суду з позовами про примусове стягнення збитків (стягується близько $10 \%$ збитків) 3 порушників законодавства про поводження з відходами, все ж таки у липні 2021 року Держекоінспекція вперше зобов'язала орган місцевого самоврядування розробити Схему санітарної очистки населеного пункту у судовому порядку. Вказана схема повинна містити комплекс заходів щодо поводження 3 відходами, а саме: збір, транспортування, захоронення, переробка сміття тощо. Так, часто масштабні порушення, серед яких: несанкціоновані сміттєзвалища, неналежна утилізація сміття та інші, пов'язані саме з відсутністю Схем саночистки [18].

Аналіз повноважень та завдань, покладених на державні органи управління поводження 3 відходами виробництва i споживання в Україні, показав, що за характером виконуваних ними функцій, можна умовно здійснити поділ органів спеціальної компетенції на органи, які здійснюють надвідомчі функції, галузеві та органи, які здійснюють окремі функції у сфері поводження 3 відходами виробництва і споживання в Україні. Так, до першої групи органів спеціальної компетенції, що здійснюють надвідомчі завдання можна віднести: Міністерство захисту довкілля та природних ресурсів України; Міністерство розвитку громад та територій України; Міністерство охорони здоров'я України. До другої групи органів спеціальної компетенції, що здійснюють галузеві завдання можна віднести: Державну екологічну інспекцію України. До третьої групи органів спеціальної компетенції, що здійснюють окремі завдання 
можна віднести: Державну службу з питань геодезії, картографії та кадастру; Державну лісову охорону.

Але, діяльність вищеперерахованих органів спеціальної компетенції в сфері поводження з відходами, на практиці не завжди $\epsilon$ узгодженою. Підставою таких неузгоджених дій є: постійні зміни в системі виконавчих органів; відсутність чіткої взаємодії; розпорошеність та дублювання повноважень органів виконавчої влади та органів місцевого самоврядування. Окрім того, слабким місцем у сфері поводження 3 відходами $\epsilon$ недостатньо налагоджена система державного моніторингу місць утворення, зберігання та видалення відходів, неналежна урегульованість на законодавчому рівні порядку здійснення державного, самоврядного та громадського контролю та слабка правореалізація норм юридичної відповідальності не сприяють правовим засадам у сфері поводження з відходами.

Для ефективного функціонування система управління відходами повинна базуватися, перш за все, на правовій основі, яка повинна бути забезпечена на місцевому рівні управління. У розвинених країнах правовою основою управління відходами $\epsilon$ цілий пакет законодавчих і нормативно-правових документів. Отже, для створення сучасної системи управління відходами в Україні необхідно розробити і прийняти цілий ряд законів і нормативних документів, які можна розділити на чотири основні групи: базові закони; закони і правила щодо окремих видів відходів; закони, що регулюють процеси переробки та захоронення відходів; закони 3 нагляду i контролю за переміщенням відходів. Ці закони повинні забезпечувати досягнення цілей управління відходами - екологічну безпеку та економічну ефективність. Однак крім законодавчої бази необхідно організувати економічно ефективне i екологічно безпечне поводження з відходами на території кожного регіону i населеного пункту. Таким чином, центр ваги в забезпеченні умов еколого-соціально-економічної спрямованості змістився на сьогоднішній день в регіони України та територіальні громади, саме тут вирішується проблема життєзабезпечення населення, а також регіональні органи управління несуть головну відповідальність перед населенням і центром за стан справ в регіоні. При цьому особливо перспективним бачиться побудова інтегрованої системи управління використанням вторинних ресурсів на регіональному рівні. Регіональне управління включає 
систему методів, механізмів і технологій, за допомогою яких здійснюється вплив на економічні, екологічні, соціальні, технікотехнологічні та інші процеси в межах даної території, спрямовані на ефективне використання наявних ресурсів 3 метою динамічного розвитку регіону і підвищення якості життя його населення. Найважливіша особливість парадигми регіонального рівня управління полягає в тому, що вона базується на сутності регіональної проблеми як багатогранного складного явища, що охоплює взаємопов'язані правові, соціальні, екологічні, організаційні та інші аспекти.

Саме регіон стає основним еколого-соціально-економічним осередком просторової організації ефективної системи управління використанням вторинних ресурсів. Підтвердженням цьому служить факт, що саме регіон має всі ознаки територіальної системи, в першу чергу властивістю цілісності, здатністю до саморозвитку, адаптації до умов, що змінюються внутрішнім i зовнішнім умовам, має закінчений цикл відтворення, специфічні важелі управління економічними, соціальними, екологічними та іншими процесами. Органи місцевого самоврядування в якості ланки регіональної економіки володіють певними повноваженнями в економічній, фінансовій, правовій сферах, що не властиве ланкам вищого рівня (наприклад економічний район) та низового рівня ієрархії - територіальна громада (місто, село, селище). Для управління системою використання вторинних ресурсів і дотримання принципу ієрархії необхідним є контроль, як функція управління, та створення для його здійснення сприятливих умов.

Контролюючими і стимулюючими факторами процесу виступають інструменти управління використанням вторинних ресурсів, що враховують особливості окремо взятого регіону управління. Для розвитку та функціонування єдиної системи управління відходами в сучасних умовах, необхідною $є$ корекція регіональної політики щодо управління відходами виробництва i споживання, а також формування економічних інструментів 3 метою створення умов для розвитку екологічного підприємництва. На сьогоднішній день просте позбавлення від відходів в біосфері поступається місцем роздумам про глибину цієї проблеми, а також спробам запровадити інтегрований підхід до управління відходами. Отже виникає необхідність в створенні механізму впровадження окремого збору відходів, з подальшим 
направленням на переробку тих відходів, які мають ресурсний потенціал. Необхідна підтримка 3 боку держави для впровадження технологій утилізації відходів, для зменшення обсягів їх розміщення в навколишньому середовищі, включаючи полігони захоронення. Важливо розробити правові, економічні та адміністративні механізми знищення відходів, накопичених, в період минулої діяльності людини.

Отже, в якості можливого вирішення проблеми нормативноправового та технологічного забезпечення поводження 3 відходами виробництва i споживання можна розглядати: вдосконалення правових та організаційних основ системи державного регулювання екологічно безпечного поводження 3 відходами, адміністративних і економічних інструментів регулювання; поліпшення системи управління відходами в умовах поділу повноважень та предметів відання між державними та регіональними органами влади, органами місцевого самоврядування; посилення контролю за виконанням природоохоронного законодавства.

\section{3. Перспективи удосконалення правового регулювання управління відходами виробництва і споживання в Україні}

Найважливішим завданням держави в галузі управління системою поводження 3 відходами $\epsilon$ створення механізмів, спрямованих на забезпечення екологічної безпеки та економне використання сировини, матеріалів, енергії та інших ресурсів. Управління системою поводження з відходами здійснюється 3 використанням нормативно-правового, економічного та суспільнополітичного механізмів. Нормативно-правовий механізм вирішує завдання управління системою поводження 3 відходами 3 використанням системи норм допустимих впливів на навколишнє середовище, системи норм і стандартів використання ресурсів, оцінки впливу на довкілля, ліцензування, системи законодавчих актів, що визначають правову основу відповідальності за порушення законодавства про поводження з відходами.

Незважаючи на те, що в останні роки в Україні чимало зроблено в сфері вдосконалення нормативно-правової бази, сучасний її рівень недостатньо ефективний, навіть враховуючи прийняття у першому читанні Проекту Закону «Про управління відходами», який теж містить певні недоліки та, на думку фахівців та експертів, містить корумповані схеми, а отже, 
потребує вдосконалення та доопрацювання [19]. Вважається, що поводження 3 відходами це найбільш корумпована галузь сфери охорони довкілля. Проблемним питанням при цьому є побудова сміттєпереробних заводів, чим вже зацікавлені зарубіжні інвестори, які, однак очікують на впевненість захисту інвестицій. Мова йде про певні природоохоронні заходи, серед яких: фільтрація, система моніторингу та постійний екологічний контроль. Крім того галузеві експерти акцентують увагу на інституційній реформі, яка повинна передувати вдосконаленню системи управління поводження з відходами. Також важливою складовою інституційної реформи має бути жорстка юридична відповідальність за порушення природоохоронного законодавства. Те що у Стратегії закладено побудову близько 20 сміттєпереробних заводів вважається катастрофою для нашої держави, поясненням чого $€$ відсутність державної системи моніторингу довкілля, насамперед повітря, а також дієвої європейської системи контролю [20].

Управління поводження відходами здійснюється на місцевому рівні, проте значимість проблеми має набагато вищий рівень: регіональний, національний, а іноді і міжнародний, в залежності від масштабів і характеру утворення відходів. Так, у 2020 році Президент Угорщини звернувся до України 3 питання припинення сміттєвого колапсу через який страждають угорці. Янош Адер закликав Україну та Румунію припинити забруднювати велику річку Тису та ії притоку Сомеш, до яких після літніх повеней потрапила величезна кількість пластикових пляшок від сусідів. Крім того Угорський президент зазначив, що 3 середини червня влада Угорщини вивезла 938 кубометрів відходів з річки Тиса та 846 кубометрів відходів з річки Сомеш [21]. Варто вказати що Україна найбрудніша країна в Європі та одна 3 найбрудніших в світі за рівнем засміченості побутовим сміттям. Ця проблема $\epsilon$ найактуальнішою, причинами якої $\epsilon$ наявність нелегальних сміттєзвалищ, відсутність переробки та сортування сміття. Тому для вирішення цієї проблеми, повинна бути розроблена чітка організаційно-правова система управління поводженням відходів в умовах ринкової економіки. Крім того на проблемні питання завжди акцентують увагу громадські організації, діяльність яких пов'язана у тому числі з вирішенням питань поводження 3 відходами. Так, голова громадської організації «Екосмарт», проблеми в сфері поводження з відходами 
пов'язує також з психологією людей стосовно цього. Мова йде про безхазяйні відходи, наявні у нашій державі та, як наслідок, безвідповідальності за наявні правопорушення в сфері поводження з відходами, на відміну від розвинених країн Європи, де $є$ поряд з тими хто продукує відходи також і власники їх. Практичним прикладом вищевказаного $\epsilon$ відповідні дані Міністерства розвитку громад та територій щодо наявності 27 тисяч несанкціонованих сміттєзвалищ, які щороку виявляють, що більш ніж в чотири рази перевищує санкціоновані. За даними Price Water House Cooper представниками тіньового бізнесу переробляється близько 15 тисяч побутових відходів, що у 5 разів перевищує показники державних структур щодо переробки побутових відходів. Що стосується проблемних питань відсутності господаря відходів, у розвинених країнах застосовується модель розширеної відповідальності виробника «проводження 3 відходами», яку було запропоновано у 90-х роках XX ст. шведським економістом Томасом Ліндквістом. Першими започаткували застосування такої моделі Німеччина та Швеція, а наразі їі вже використовують 26 держав членів Європейського Союзу та інші держави, які не входять до $\epsilon$. Модель розширеної відповідальності виробника передбачає системну відповідальність, та включає поняття «циркулярна економіка» за якою сміття $\epsilon$ цінним ресурсом та підлягає подальшій переробці, за яку відповідальним $\epsilon$ саме господар відходів. Умовами моделі розширеної відповідальності є обов'язок країн які її застосовують, поступово підвищувати цільові показники його збирання та переробки [22]. Однак, наразі, незрозумілим $є$ те, як працюватиме в Україні модель розширеної відповідальності виробника. Отже, $\epsilon$ низка питань, які потребують вирішення стосовно вказаних проблемних питань поводження з відходами.

До теперішнього часу не завершено процес розмежування предметів відання і повноважень в галузі поводження з відходами між державними органами виконавчої влади, органами державної влади на місцях і органами місцевого самоврядування. Органи місцевого самоврядування, на які в законодавчому порядку покладено всю відповідальність за організацію збору та утилізації відходів, не в змозі самостійно вирішити цю задачу. В регіональних і місцевих системах має місце ряд об'єктивних і суб'єктивних факторів, що впливають позитивно або негативно на процеси поводження 3 відходами. До числа проблемних 
ситуацій відносяться низька економічна і соціальна ефективність заходів в цій сфері, відсутність системи економічного стимулювання діяльності підприємств, що переробляють відходи, розвитку маловідходного і безвідходного виробництв, слабка координація діяльності суб'єктів у сфері поводження відходів органами місцевої влади; відсутність методичних підходів щодо формування організаційно-економічної системи управління поводження з відходами на території відповідної територіальної громади. Їх суть полягає в створенні нормативно-правових, економічних і науково-технічних умов для скорочення втрат i підвищення ефективності використання матеріально-сировинних ресурсів, які повинні передбачати підвищення ефективності ринкових механізмів у сфері: стандартизації ресурсозбереження; використання вторинної сировини; використання екологічного законодавства з метою жорсткого обмеження споживання всіх видів природної сировини, ресурсів та енергії; розробку економічних, технічних і технологічних нормативів, розробку науково-технічних та інноваційних заходів; формування регіональної і муніципальної систем економічного стимулювання підприємств, установ і населення в сфері обігу відходів; створення механізмів державного регулювання, створення координаційних центрів з забезпечення поводження з відходами на території відповідної територіальної громади.

3 усіх можливих напрямків поводження з відходами найбільш екологічно безпечна і краща їх переробка (утилізація), особливо в рамках створення маловідходних і безвідходних технологій. При маловідходному виробництві шкідливий вплив на навколишнє середовище не перевищує рівня, що допускається санітарними органами, але частина сировини і матеріалів все ж переходить у відходи і відправляється на поховання, а при безвідходному виробництві не повинно відбуватися викидів в навколишнє середовище, необхідне максимальне і комплексне використання сировини та досягається теоретично можливий мінімум відходів усіх видів.

Важливе значення має кількісна оцінка наближення виробництва до безвідходного, тобто критерій віднесення його до категорії безвідходних, маловідходних і традиційних. На сьогоднішній день універсального критерію немає, але в різних галузях народного господарства нашої країни вже введені відповідні показники. В основу їх покладено існуючі санітарно- 
гігієнічні нормативи - гранично допустимі концентрації забруднюючих речовин, і науково-технічні показники впливу виробництва на навколишнє середовище, до яких відносяться нормативи гранично допустимих викидів в атмосферу і гранично допустимих скидів у водойми. Як правило, це завдання вирішується в рамках державних (національних) програм 3 виділенням істотних фінансових ресурсів на вказані цілі.

3 метою ефективного управління відходами необхідно розробити стратегію поводження 3 ними, що враховує весь комплекс складових цього процесу і специфічні місцеві умови кожного населеного пункту. Пріоритетними напрямками в галузі поводження з відходами повинні бути наступні: запобігання утворенню відходів; максимально можливе зниження вмісту небезпечних речовин у відходах і шкоди, завданої ними; максимально можлива утилізація, вторинне використання, рециклінг i компостування використовуваних компонентів відходів; екологічно чисте видалення (захоронення) решти відходів.

Стратегічний підхід до управління поводження відходів передбачає перш за все дотримання таких принципів: планувати діяльність щодо поводження з відходами до їх утворення, бути готовими до зміни обсягів відходів, що утворюються; займатися не тільки поточним управлінням відходами, а й планувати діяльність в цій сфері на середньо- і довгострокову перспективу; законодавчо закріпити основні правила поводження з відходами, а також перспективні цілі відповідної діяльності; мати оперативну і прогнозну інформацію про характеристики процесу поводження 3 відходами на всіх стадіях; застосовувати індивідуальний підхід до поводження з різними видами відходів: медичними, будівельними тощо; планувати впровадження сучасних технологій, модернізацію виробничого процесу на всіх стадіях поводження 3 відходами; залучати різні джерела фінансування заходів щодо поводження 3 відходами, забезпечуючи максимальну віддачу від вкладених коштів; враховувати думки всіх учасників процесу поводження 3 відходами під час прийняття рішень; планувати діяльність щодо кадрового забезпечення процесу поводження з відходами, що припускає підвищення кваліфікації співробітників, підготовку молодих фахівців тощо; формувати системи економічних i регулюючих інструментів, застосування яких дозволить 
Новітні досягнення та вектори розвитку сучасної юриспруденції

забезпечити відповідність стратегічним цілям поводження 3 відходами всіх учасників цього процесу.

Таким чином, щоб стимулювати в нашій країні процес збору і переробки відходів і створити для цього більш сприятливі умови, доцільним вважається вжиття таких заходів: 1) ввести законодавче положення, згідно 3 яким господарське використання відходів стає спеціально виділеним об'єктом державного регулювання, наділивши при цьому одне 3 міністерств чи відомств повноваженнями щодо здійснення державної політики в цій галузі; 2) ввести систему загальної відповідальності за організацію збору та переробки відходів, поклавши цю відповідальність на: господарюючих суб'єктів як власників відходів виробництва; фізичних осіб як власників побутових відходів; органи місцевого самоврядування як на суб'єктів, що організують збір, вивезення, переробку та захоронення відходів; 3) потрібно створити нормативно-правові умови для більш ефективного використання природоохоронних механізмів і інструментів державного регулювання - дозвільної системи розміщення відходів з встановленням лімітів, платежів за розміщення відходів, ліцензування, оцінки впливу на довкілля; 4) особливі нормативно-правові умови слід також створити для застосування традиційних методів державного регулювання підприємницької діяльності в даній сфері: податкові пільги, зниження норми амортизації та орендної плати, державного замовлення; 5) одним із шляхів вирішення проблеми може бути залучення приватного капіталу у формування полігонного комплексу. Відповідно до законодавства та бюджетними відносинами, як варіант, це можливо за рахунок наступних схем: надання спеціальної форми бюджетного кредитування у вигляді іпотеки на будівництво полігону; введення податкових преференцій при створенні сучасних комплексів утилізації відходів; гнучкої системи тарифних платежів для підприємств і населення, в тому числі і за рахунок тимчасових дотацій.

3 метою вирішення проблем нормативно-правового регулювання в галузі поводження 3 відходами, створення економічно ефективних інституційних і організаційних умов в галузі поводження 3 відходами, вдосконалення управління відходами в Україні, скорочення утворення відходів, розвитку маловідходних технологій, максимального залучення відходів в господарський оборот, посилення контролю за виконанням 
природоохоронного законодавства в сфері поводження 3 відходами, слід запропонувати: проведення інвентаризації місць захоронення відходів виробництва і споживання з метою оцінки впливу їх на навколишнє середовище i визначення місць захоронення відходів виробництва і споживання, що підлягають рекультивації; розробку проектних пропозицій і проведення передпроектних робіт щодо приведення місць захоронення відходів виробництва і споживання у відповідність з природоохоронними вимогами; створення на основі муніципального замовлення комплексної системи управління та договірних відносин від джерела утворення відходів виробництва i споживання до їх захоронення на полігонах 3 прозорим i повноцінним фінансовим забезпеченням кожної стадії процесу; залучення малого і середнього бізнесу на основі приватнодержавного партнерства в процеси збору, транспортування та переробки відходів виробництва і споживання; організацію селективного (роздільного) збору відходів виробництва i споживання в населених пунктах, в процес якого необхідно залучити населення, застосувавши систему винагород та матеріального стимулювання за здану вторинну сировину.

\section{Висновки}

у дослідженні обгрунтовано організаційно-інституційні засади побудови системи управління відходами в просторі регіону та відповідної територіальної громади в контексті концептуальних установок правової і екологічної орієнтації економіки, що забезпечує адекватне відображення суті існуючих тенденцій. В основі наукової гіпотези дослідження системи управління відходами в регіонах лежить теза про іï детермінованості завданнями вирішення проблем не тільки екологічного характеру, а й економічно-правового.

Крім того проаналізована система управління відходами, що $\epsilon$ базисом для розробки і впровадження відповідних Регіональних планів управління відходами для будь-якого регіону України. Певний регіональний план управління відходами повинен враховувати особливості кожного окремого регіону - структуру і обсяги регіонального виробництва, кількість населення, рівень його життя, обсяги i склад відходів, що утворюються, інфраструктуру регіону тощо. 
Більш детальному нормативно-правовому регулюванню підлягають відносини між суб'єктами, які здійснюють діяльність щодо поводження з відходами, в зв'язку з чим пропонується: підготовка та прийняття відсутнього в даний час нормативного правового акту, що містить систему екологічних вимог щодо управління та поводження з відходами; закріпити заборону на розміщення об'єктів знешкодження відходів в межах населених пунктів в положеннях Закону України «Про відходи»; встановити, або посилити систему екологічних вимог до процесів проектування, будівництва, введення в експлуатацію, експлуатації та виведення з експлуатації (консервації і ліквідації) об'єктів знешкодження відходів в нормативному правовому акті підзаконного характеру.

\section{Література:}

1. Конституція України від 28 червня 1996 року. URL: http://zakon.rada.gov.ua/go/254к/96-вр (дата звернення: 10.09.2021).

2. Про приєднання України до Базельської конвенції про контроль за транскордонними перевезеннями небезпечних відходів та їх видаленням: Закон України від 01.06.1999 р. № 803-XIV. URL: https://zakon.rada.gov.ua/laws/show/803-14\#Text (дата звернення: 10.09.2021).

3. Стокгольмська конвенція про стійкі органічні забруднювачі 2001 p. URL: https://zakon.rada.gov.ua/laws/show/ 995_a07\#Text (дата звернення: 10.09.2021).

4. Про охорону навколишнього природного середовища: Закон України від 25.06.1991p. № 1264-XII. Дата оновлення: 01.01.2021. URL: https://zakon.rada.gov.ua/laws/show/126412\#Text (дата звернення: 10.09.2021).

5. Про відходи: Закон України від 05.03.1998 р. № 187/98-ВР. Дата оновлення: 16.10.2020. URL: https://zakon.rada.gov.ua/ laws/show/187/98-\%D0\%B2\%D1\%80\#Text (дата звернення: 10.09.2021).

6. Національна стратегія управління відходами в Україні до 2030 року: Постанова Кабінету Міністрів України від 08.11.2018 p. № 820. URL: https://zakon.rada.gov.ua/laws/show/ 820-2017-\%D1\%80\#Text (дата звернення: 10.09.2021).

7. Про затвердження Національного плану управління відходами до 2030 року: Розпорядження Кабінету Міністрів 
України від 20.02.2019 p. № 117-p. URL: https://www.kmu.gov.ua/ npas/pro-zatverdzhennya-nacionalnogo-planu-upravlinnyavidhodami-do-2030-roku (дата звернення: 10.09.2021).

8. Directive 2008/98/EC of the European Parliament and of the Council of 19 Nov 2008 on waste and repealing certain Directives. URL: https://www.legislation.gov.uk/eudr/2008/98/contents (дата звернення: 10.09.2021).

9. Рамкова Директива про відходи 75/442/ЄС від 15 липня 1975 p. рішенням Європейської Ради. URL: https://eurlex.europa.eu/legalcontent/EN/TXT/PDF/?uri=CELEX:31975L0442\&f $\mathrm{rom}=\mathrm{EN}$ (дата звернення 10.09.2021).

10.Про місцеві державні адміністрації: Закон України від 09.04.1999 p. № 586-XIV. Дата оновлення: 01.08.2021 p. URL: https://zakon.rada.gov.ua/laws/show/586-14\#Text звернення: 10.09.2021).

11. Про місцеве самоврядування в Україні: Закон України від 21.05.1997 p. № 280/97-BP. Дата оновлення: 27.05.2021. URL: https://zakon.rada.gov.ua/laws/show/280/97-\%D0\%B2\%D1\%80 (дата звернення: 10.09.2021).

12. Деякі питання Міністерства захисту довкілля та природних ресурсів: Постанова Кабінету Міністрів України від 25.06.2020 р. № 614. URL: https://zakon.rada.gov.ua/laws/show/614-2020\%D0\%BF\#Text (дата звернення: 10.09.2021).

13. Про затвердження Положення про Міністерство розвитку громад та територій України: Постанова Кабінету Міністрів України від 30.04.2014 p. № 197. URL: https:// zakon.rada.gov.ua/laws/show/197-2014-\%D0\%BF\#Text (дата звернення: 10.09.2021).

14. Про затвердження Державних санітарно-протиепідемічних правил і норм щодо поводження з медичними відходами: наказ Міністерства охорони здоров'я України 08.06.2015 р. № 325. URL: https://zakon.rada.gov.ua/laws/show/z0959-15\#Text (дата звернення: 10.09.2021).

15. Положення про Державну екологічну інспекцію: постанова Кабінету Міністрів України від 19.04.2017 р. № 275. URL: https://zakon.rada.gov.ua/laws/show/275-2017-\%D0\%BF\#Text (дата звернення: 10.09.2021).

16. Про основні засади державного нагляду і контролю у сфері господарської діяльності: Закон України від 05.042007 р. 
№ 877-V. URL: https://zakon.rada.gov.ua/laws/show/877-16\#top (дата звернення: 10.09.2021).

17.Голова Держекоінспекції Андрій Мальований: Прийняття екологічного закону важливіше, ніж керувати стерилізованим органом. URL: https://www.dei.gov.ua/posts/1768 (дата звернення: 10.09.2021).

18.Сміттєвий колапс на Київщині: збитки довкіллю сягають майже 9 млн грн. URL: https://glavcom.ua/kyiv/news/smittjeviykolaps-na-kijivshchini-zbitki-dovkillyu-syagayut-mayzhe-9-mln-grnfoto-770783.html (дата звернення: 10.09.2021).

19.Проект Закону про управління відходами: Законопроект від $\quad 04.06 .2020$ р. № 2207-1-д. URL: https://w1.c1.rada.gov.ua/ pls/zweb2/webproc4_1?pf3511=69033 (дата звернення: 10.09.2021).

20.Українське сміття, довкілля і «фактор Юрченка»: чого чекати Україні?. URL: https://www.radiosvoboda.org/a/ukrainskesmittya-dovkillya-i-faktor-yurchenka/30851454.html (дата звернення: 10.09.2021).

21.Сміттєвий колапс чи сортування: куди рухається Україна?. URL: https://www.pravda.com.ua/columns/2021/03/16/7286845/ (дата звернення: 10.09.2021).

22.Управління відходами і психологія, або Чому сміття може не пустити Україну в ЄC. URL: https://www.pravda.com.ua/ columns/2021/09/11/7306586/ (дата звернення: 10.09.2021). 